\title{
Distinctions in DNA and protein profiles among clinical isolates of Mycoplasma pneumoniae
}

\author{
C. J. Su, S. F. Dallo, H. Alderman and J. B. Baseman* \\ Department of Microbiology, The University of Texas Health Science Center at San Antonio, 7703 Floyd Curl Drive, \\ San Antonio, Texas 78284-7758, USA
}

(Received 17 May 1991; revised 12 August 1991; accepted 5 September 1991)

\begin{abstract}
Clinical isolates of Mycoplasma pneumoniae previously shown to exhibit significant sequence divergency in a major 170 kDa adhesin, designated P1, were further characterized using restriction enzyme fingerprinting of genomic DNA and two-dimensional gel electrophoresis of total proteins. Numerous differences in DNA restriction patterns and protein profiles were found, possibly reflecting various degrees of virulence and antigenic potential.
\end{abstract}

\section{Introduction}

Mollicutes (mycoplasmas) are cell-wall-less prokaryotes representing the smallest self-replicating organisms. Their genomes are double-stranded circular DNA ranging in size from 400 to $1000 \mathrm{MDa}$ (Morowitz \& Wallace, 1973; Razin, 1985; Su \& Baseman, 1990) and are distinguished by a low guanine plus cytosine $(\mathrm{G}+\mathrm{C})$ content, between 23 to $40 \%$ (Razin, 1985).

The genus Mycoplasma contains many species that are pathogenic for a wide variety of plants and animals (Freundt \& Edward, 1979). In humans, Mycoplasma pneumoniae infects the lower respiratory tract and is the causative agent of primary atypical pneumonia (Chanock et al., 1962; Eaton et al., 1945; Grayston et al., 1965). A $170 \mathrm{kDa}$ protein $(\mathrm{P} 1)$ has been identified as a major cytadhesin and virulence factor (Baseman et al., 1982; Feldner et al., 1982; Hu et al., 1982), and the gene has been cloned and sequenced (Inamine et al., 1988; Su et al., 1987). Using subclones of the cytadhesin gene as probes in Southern blot analysis of clinical isolates, we classified M. pneumoniae into two groups (I and II) based upon different hybridization patterns (Dallo et al., 1990; $\mathrm{Su}$ et al., 1990b). Further analysis of their P1 genes revealed two stretches of significant sequence divergency (Su et al., 1990a). One region was about 500 bp in which the two groups shared $72 \%$ DNA homology; the other was about $700 \mathrm{bp}$ in which the two groups shared $90 \%$ homology. Both nucleotide stretches were located in multiple-copy regions of the Pl gene (Su et al., 1988), raising the possibility that the observed sequence

Abbreviation: NEPHGE, non-equilibrium pH gradient
electrophoresis.

divergency arose from recombination between homologous yet slightly different regions of the chromosome.

To elucidate further the distinctions between these two groups of $M$. pneumoniae, representative strains from each group were selected for further analysis using restriction enzyme fingerprinting and two-dimensional gel electrophoresis.

\section{Methods}

Origin of $M$. pneumoniae strains. $M$. pneumoniae M129-B16 (ATCC 29342) was originally isolated from a patient in 1968 (Lipman \& Clyde, 1969). Strain FH (ATCC 15531) (Chanock et al., 1962) was obtained from the American Type Culture Collection. Strain TW 7-5 was obtained from J. G. Tully (National Institute of Allergy and Infectious Diseases, Bethesda, Md., USA) and originated from a $M$. pneumoniae vaccine trial conducted with military recruits in 1974 and 1975 (Wenzel et al., 1976). Strain UTMB was isolated from the synovial fluid of an arthritic patient by C. P. Davis (University of Texas Medical Branch at Galveston, USA) (Davis et al., 1988). Strain PN 597 was obtained in the 1960s from a patient in Seattle (Wash., USA) (Foy et al., 1970; Grayston et al., 1965; Vu et al., 1987).

DNA fingerprinting. DNA was purified from group I (M12-B16 and PN 597) and group II (FH, TW 7-5 and UTMB) M. pneumoniae strains according to published methods (Su et al., 1987). Purified DNA was dissolved in TE buffer $(10 \mathrm{~mm}$-Tris/ $\mathrm{HCl}, \mathrm{pH} \mathrm{8.0,1} \mathrm{mm}$-EDTA), quantified and stored at $4{ }^{\circ} \mathrm{C}$. Restriction enzymes were purchased from BRL and NEB. Each DNA preparation $(8 \mu \mathrm{g})$ was digested overnight with 20 to 30 units of specific restriction enzymes in a total volume of $50 \mu \mathrm{l}$ at $37^{\circ} \mathrm{C}$, and the DNA was separated by agarose gel electrophoresis (Maniatis et al., 1982). DNA from each group was digested with the same enzymes and loaded side-by-side during electrophoresis. Enzymes were selected that did not cut $M$. pneumoniae genomic DNA frequently and, therefore, were more likely to produce unique restriction patterns. Because of the low $\mathrm{G}+\mathrm{C}$ content of the $M$. pneumoniae genome, enzymes were evaluated that specifically recognized 6 bp sequences in which at least four nucleotides were either 
guanine or cytosine. After electrophoresis was completed, DNA gels were stained with ethidium bromide and photographed.

Reverse field electrophoresis of DNA. Because digestion with restriction enzymes as above generated high molecular mass DNA bands that were not well-resolved by conventional electrophoresis, reverse field gel electrophoresis (Carle et al., 1986) was employed. $M$. pneumoniae strains were encapsulated in agarose beads according to the method of Jackson \& Cook (1985). Cells were lysed in situ by addition of $1 \%$ SDS and $0.25 \mathrm{M}$-EDTA, and proteins were digested with proteinase $\mathrm{K}$ (Boehringer) at $50^{\circ} \mathrm{C}$ overnight. The agarose beads were washed three times with 10 vols of wash buffer $(10 \mathrm{~mm}-\mathrm{Tris} / \mathrm{HCl}, \mathrm{pH} 8.0$, $10 \mathrm{~mm}$-EDTA) containing $2 \mathrm{~mm}$-PMSF and stored at $4{ }^{\circ} \mathrm{C}$. Before restriction enzyme digestion, the DNA-containing agarose beads were equilibrated with the appropriate reaction buffer. The amount of agarose beads used was determined empirically to produce sharp bands (about 20 to $50 \mu \mathrm{l}$ of agarose beads) under the selected conditions. DNA was digested, loaded into wells and sealed with $0.5 \%$ agarose solution before electrophoresis. Reverse field electrophoresis was performed on $0.8 \%$ agarose gels in $0.5 \times$ TBE buffer $(1 \times$ TBE is $90 \mathrm{mM}$-Tris, $45 \mathrm{mM}$ boric acid, and $0.5 \mathrm{mM}$-EDTA) at room temperature with buffer recirculation using a M.J. programmable power inverter PPI-200 (M.J. Research Inc., Cambridge, Mass., USA). The voltage was set at $7 \mathrm{~V}$ $\mathrm{cm}^{-1}$ and electrophoresis was continued for 18 to $20 \mathrm{~h}$. Preset programme 3 was used to resolve DNA bands in the 10 to $50 \mathrm{~kb}$ range; programme 4 was used to resolve bands in the 30 to $200 \mathrm{~kb}$ range.

Preparation of cell samples for two-dimensional gel electrophoresis. Glass-adherent cells of $M$. pneumoniae isolates from a single culture bottle (about $950 \mathrm{ml}$ ) were washed six times with cold phosphatebuffered saline (PBS; 0.145 M-NaCl, 0.017 M- $\mathrm{Na}_{2} \mathrm{HPO}_{4}, 0.003 \mathrm{M}-$ $\mathrm{NaH}_{2} \mathrm{PO}_{4}, \mathrm{pH} \mathrm{7.2}$ ), scraped into $5 \mathrm{ml}$ PBS and centrifuged at $9500 \mathrm{~g}$ for $20 \mathrm{~min}$. Cell pellets were resuspended uniformly in $190 \mu 10.05 \mathrm{M}$ Tris/HCl (pH 6.8) and $15 \mu \mathrm{l} \mathrm{2-mercaptoethanol} \mathrm{according} \mathrm{to} \mathrm{Ames} \mathrm{\&}$ Nikaido (1976). Individual samples were vortexed for $10 \mathrm{~min}$ followed by the addition of $53 \mu 110 \%$ (w/v) SDS and $15 \mu \mathrm{l} 2$-mercaptoethanol. Tubes were heated at $100^{\circ} \mathrm{C}$ for $4 \mathrm{~min}$, cooled to room temperature and $95 \mu \mathrm{l}$ of the resulting preparation was added to $55 \mathrm{mg}$ urea in a new tube. After dissolution of the urea at $37^{\circ} \mathrm{C}, 100 \mu \mathrm{l}$ of the resulting preparation was added to $205 \mu \mathrm{l}$ of lysis buffer (Ames \& Nikaido, 1975). A $20 \mu \mathrm{l}$ vol. of this solution, representing approximately $75 \mu \mathrm{g}$ protein, was used for two-dimensional gel electrophoresis.

Two-dimensional gel electrophoresis. Non-equilibrium pH gradient electrophoresis (NEPHGE) was performed in $100 \mu \mathrm{l}$ capillary tubes by the procedure of O'Farrell et al. (1977), using pH 3 to 10 ampholines (Bio-Rad) and an electrophoresis period of $2 \mathrm{~h}$ at $500 \mathrm{~V} \cdot \mathrm{h}$. Tube gels were equilibrated for $15 \mathrm{~min}$ in SDS sample equilibration buffer (12.5 ml 0.5 M-Tris/HCl, pH 6.8, $23 \mathrm{ml} \mathrm{10 \%} \mathrm{SDS,} 5 \mathrm{ml}$ 2-mercaptoethanol, $8 \mathrm{ml}$ glycerol, $2.5 \mathrm{ml} 0.05 \%$ bromophenol blue, $49 \mathrm{ml}$ water to make $100 \mathrm{ml}$ total volume). SDS gel electrophoresis was performed using $7.5 \%$ polyacrylamide separating gels and $4 \%$ polyacrylamide stacking gels, prior to staining with silver (Merril et al., 1979; O'Farrell et al., 1977). Immunoblots were performed according to the method of Towbin et al. (1979) using hyperimmune rabbit sera raised against $M$. pneumoniae strain M129-B16.

\section{Results}

Several enzymes produced DNA restriction patterns that discriminated between all group I and group II $M$. pneumoniae strains using conventional agarose gel electrophoresis (Fig. 1). However, because many high molecular mass DNA fragments generated by these enzymes could not be resolved by conventional gel electrophoresis, reverse field gel electrophoresis (Carle $e t$ al., 1986) was employed. Fig. 2 shows the reverse field electrophoresis patterns. When digested with ApaI both group I and group II genomes were resolved into at least 11 bands, some of which appeared to be doublets or triplets. The position of at least two bands differed between group I and group II strains. In group I the top two bands were at $250 \mathrm{~kb}$ and $110 \mathrm{~kb}$, whereas in group II these bands were at $190 \mathrm{~kb}$ and $130 \mathrm{~kb}$. NarI digestion also revealed differences between group I and group II genomes. Bands at $130 \mathrm{~kb}$ and $90 \mathrm{~kb}$ in group I appeared as $150 \mathrm{~kb}$ and $100 \mathrm{~kb}$ in group II; other bands appeared identical. When digested with $X$ hoI, besides the $12.5 \mathrm{~kb}$ band detected by conventional electrophoresis, group I displayed an extra band at $50 \mathrm{~kb}$ (possibly a doublet). In contrast, group II possessed a band at $110 \mathrm{~kb}$ not present in group I. Other restriction enzymes ( $S a c \mathrm{I}$ and $P v u \mathrm{I}$ ) revealed additional differences between group I and group II DNA (Fig. 2). However, RsrII digested DNA of both groups into at least 11 bands with apparently identical sizes (Fig. 2). Three of these bands appeared to be doublets (bands II, V and VII from top to bottom, Fig.

Table 1. DNA restriction fragment differences between group I and group II M. pneumoniae strains

\begin{tabular}{|c|c|c|}
\hline \multirow[b]{2}{*}{ Enzyme } & \multicolumn{2}{|c|}{ Restriction fragments (kb) } \\
\hline & Group I & Group II \\
\hline \multirow[t]{5}{*}{ ApaI } & 250 & - \\
\hline & - & 190 \\
\hline & - & 130 \\
\hline & 110 & - \\
\hline & $2 \cdot 5$ & - \\
\hline \multirow[t]{4}{*}{ NarI } & - & 150 \\
\hline & 130 & - \\
\hline & - & 100 \\
\hline & 90 & - \\
\hline \multirow[t]{4}{*}{$P v u \mathrm{I}$} & - & - \\
\hline & 25 & - \\
\hline & - & 12 \\
\hline & - & 7 \\
\hline \multirow[t]{5}{*}{$S a c I$} & - & 30 \\
\hline & 22 & - \\
\hline & 20 & - \\
\hline & - & 12 \\
\hline & - & 5 \\
\hline \multirow[t]{4}{*}{ SacII } & $8 \cdot 5$ & - \\
\hline & - & $5 \cdot 0$ \\
\hline & - & 4.0 \\
\hline & $3 \cdot 2$ & - \\
\hline \multirow[t]{2}{*}{ SalI } & - & 18 \\
\hline & - & $3 \cdot 3$ \\
\hline \multirow[t]{3}{*}{ XhoI } & - & 110 \\
\hline & 50 & - \\
\hline & $12 \cdot 5$ & 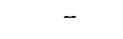 \\
\hline
\end{tabular}



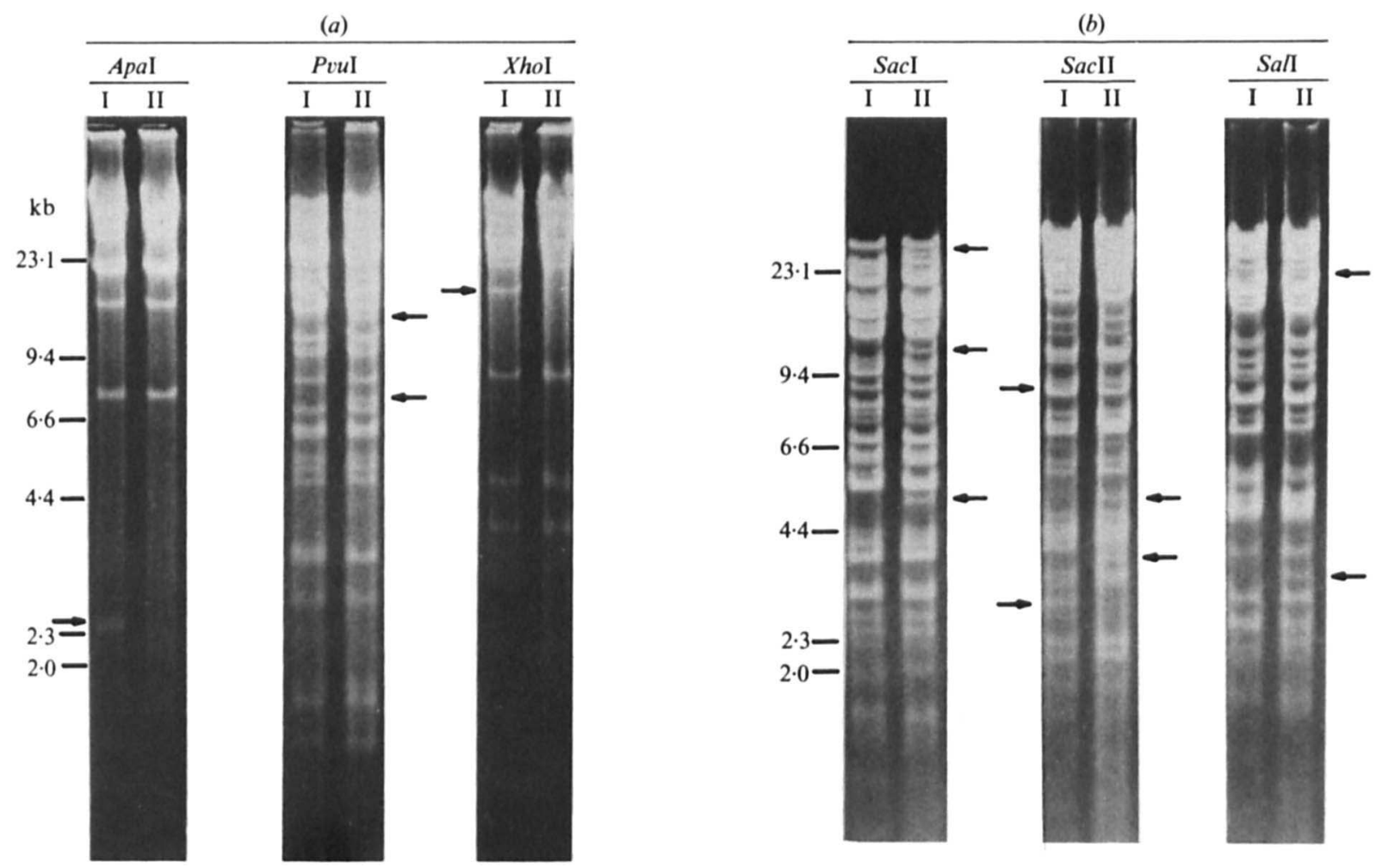

Fig. 1. Restriction fragment differences between group I and group II $M$. pneumoniae chromosomes as indicated by conventional agarose gel electrophoresis. (a) DNA separated on $0.7 \%$ agarose gels; $(b)$ DNA separated on $0.5 \%$ agarose gels. Numbers on the left are molecular size standards in $\mathrm{kb}$. Arrows point to the observed differences in restriction fragments. Under each restriction enzyme name, group I DNA (I) is represented by strain M129-B16, and group II DNA (II) is represented by strain UTMB (Su et al., 1990b).
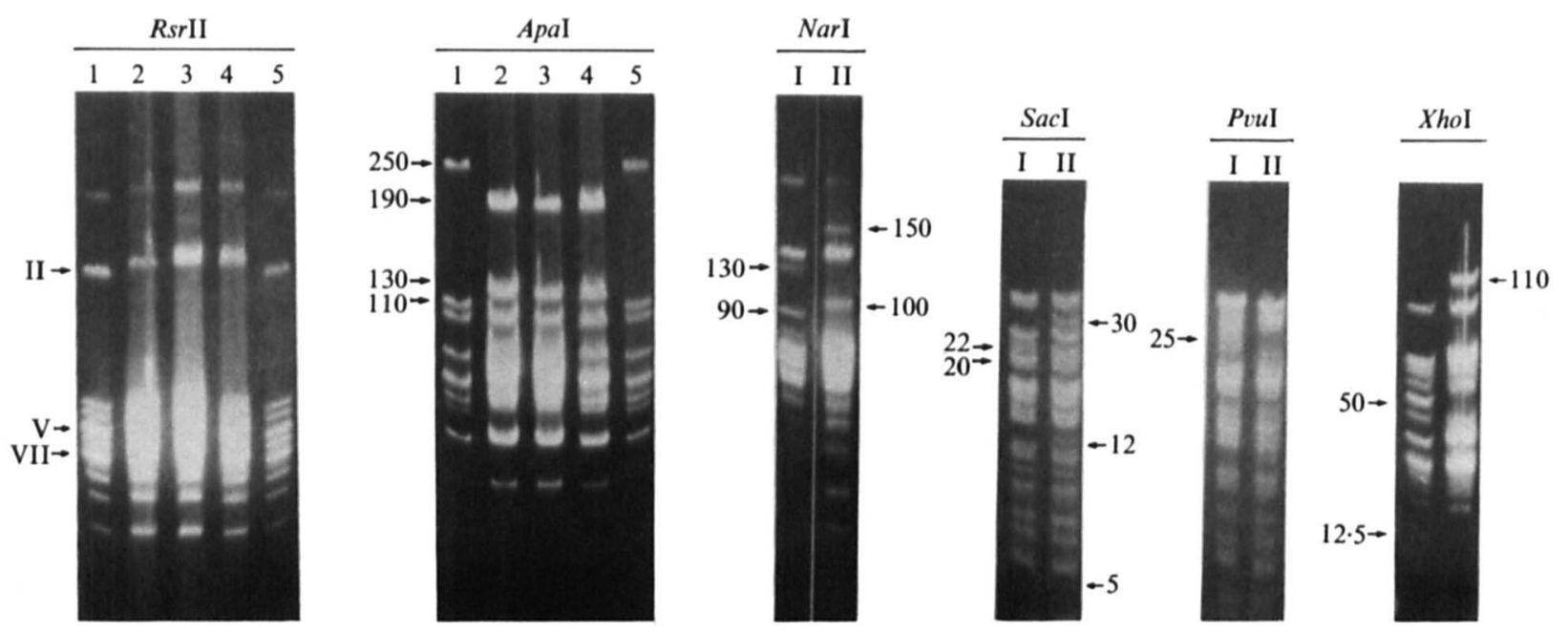

Fig. 2. Restriction fragment differences between group I and group II $M$. pneumoniae chromosomes as indicated by reverse field gel electrophoresis. For RsrII and ApaI, 1 and 5 represent group I DNA of strains M129-B16 and PN597, respectively; lanes 2, 3 and 4 are group II DNA of strains UTMB, TW7-5 and FH, respectively (Su et al., 1990b). For the other enzymes, group I DNA (I) is represented by strain M129-B16 and group II DNA (II) by strain UTMB. For RsrII II, V and VII indicate three doublet DNA bands. For the other enzymes, arrows indicate fragments of different sizes between group I and group II strains. Numbers are the estimated molecular size in kb. 


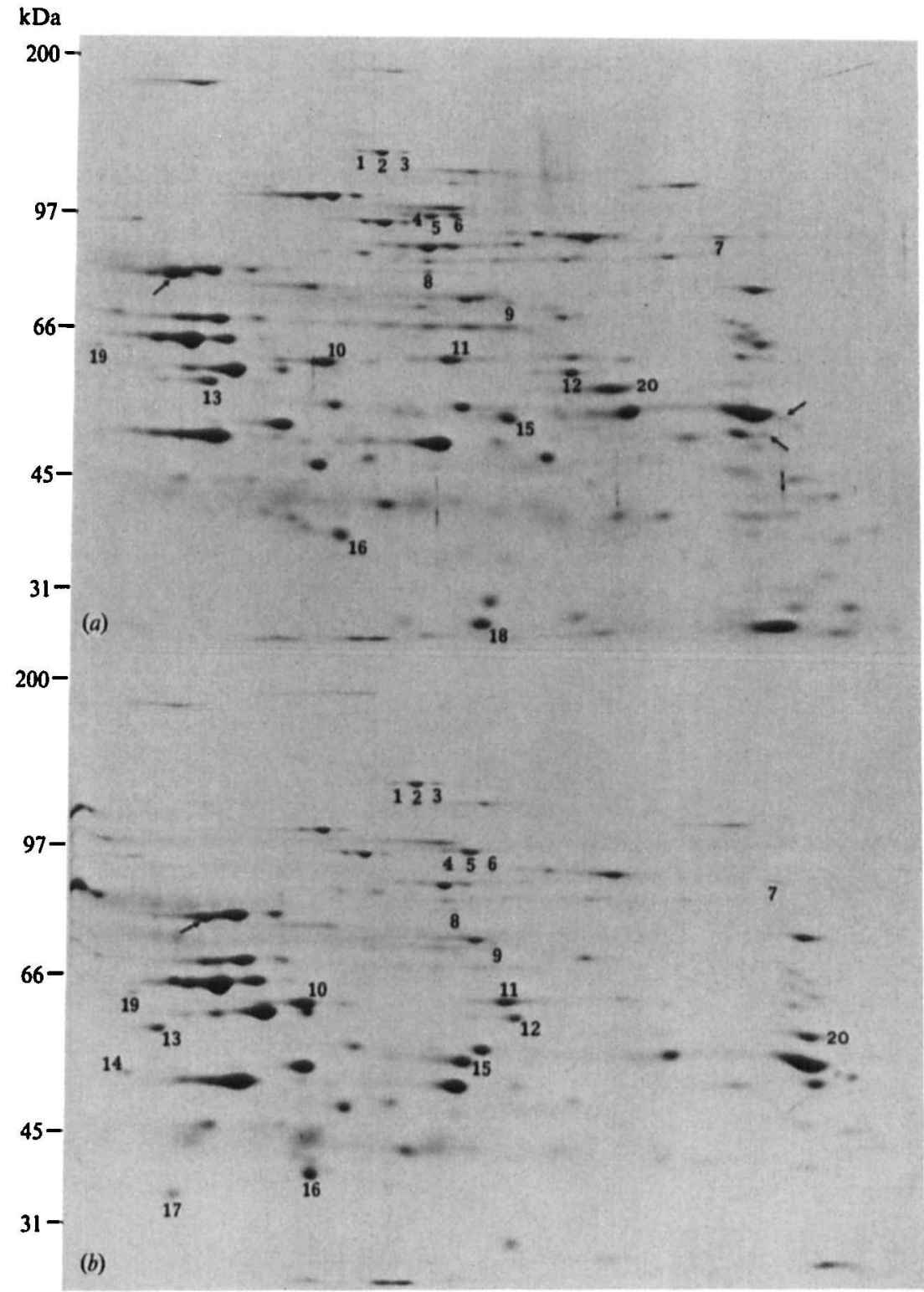

Fig. 3. NEPHGE-SDS electrophoretic analysis of proteins (silver-stained) from (a) $M$. pneumoniae M129-B16 and (b) clinical isolate TW7-5. Protein spots that show differences between $(a)$ and $(b)$ are numbered. Arrows on the left represent possible differences in separation of proteins upon migration in first-dimension electrophoresis; arrows on the right represent possible quantitative differences in specific proteins. Orientation of NEPHGE is basic (left) to acidic (right). Positions of molecular mass standards $(\mathrm{kDa})$ are indicated. All strains within each group displayed identical electrophoretic patterns.
2). Based upon these restriction patterns the total $\mathrm{kb}$ value of the mycoplasma genomes was determined to be approximately $850 \mathrm{~kb}$ which is in good agreement with published data on M. pneumoniae genome size (Wenzel \& Herrmann, 1988; Krause \& Mawn, 1989). Table 1 summarizes the observed differences between the group I and group II $M$. pneumoniae genomes. Overall, the two groups of $M$. pneumoniae showed much similarity in their DNA restriction patterns as would be expected, but minor differences existed that might have clinical and biological significance (Dallo et al., 1990; Su et al., $1990 a, b$ ).

Since the observed differences in DNA restriction patterns may result in changes at the protein level, two- dimensional SDS-PAGE was performed to compare group I and group II $M$. pneumoniae strains. The silverstained gels revealed many differences, mostly reflected in apparent changes in the isoelectric point of specific proteins (Fig. 3). Spots corresponding to proteins numbered 14 and 17 were not readily identifiable in group I $M$. pneumoniae under these experimental conditions while protein number 18 was missing in group II clinical isolates. Other protein differences are indicated by numbers and arrows.

In order to determine whether the proteins associated with altered migration properties were antigenic, immunoblots of two-dimensional gels of each $M$. pneumoniae strain were prepared using hyperimmune rabbit sera 
to $M$. pneumoniae M129-B16. In most cases the proteins identified in group I mycoplasmas along with the corresponding proteins in group II mycoplasmas were antigenic (data not shown).

\section{Discussion}

Previously, we classified clinical isolates of M. pneumoniae into two groups, I and II, based upon the diversity of their major cytadhesin Pl gene (Dallo et al., 1990; Su et $a l ., 1990 a, b)$. Further analysis of these mycoplasma strains by restriction enzyme fingerprinting of the chromosomal DNA and two-dimensional gel electrophoresis of proteins has further established molecular distinctions among these two groups. With DNA fingerprinting, in addition to the $12 \mathrm{~kb}$ HindIII band reported previously (Su et al., 1990b), enzymes such as ApaI, NarI, PvuI, SacI, SacII, SalI and XhoI further discriminated between group I and group II $\boldsymbol{M}$. pneumoniae isolates. Within each group, we have not yet observed variations in the restriction enzyme fingerprinting profile. On the other hand, restriction fragments generated by other restriction enzymes, such as EcoRI or SmaI (Dallo et al., 1990), and RsrII (Fig. 2) reveal no differences indicating that $M$. pneumoniae as a species has preserved overall genetic homology. Chandler et al. (1982) studied the genomic and phenotypic differences of five strains of M. pneumoniae (PI-1428, M129, B176, FH and Mac). They found that DNA cleavage patterns produced by $X b a \mathrm{I}$ and $E c o$ RI were similar with the exception of strains FH and Mac (group II) that differed slightly from the other three strains (M129-B16 belongs to group I). They concluded that because of its restricted ecological niche, $M$. pneumoniae as a species was remarkably stable (Su et al., 1988).

The differences in DNA fingerprinting patterns observed between the two groups could reflect distinct restriction site arrangements and unique DNA sequences in each genome. We have detected two stretches of major differences in nucleotide sequences $(72 \%$ and $90 \%$ homology) in the $\mathrm{Pl}$ cytadhesin genes in these two groups (Su et al., 1990a). In addition, some alterations in DNA fingerprinting patterns could be caused by distinct restriction modification patterns of the genomes involving methylation of cytosine or adenine at specific restriction sites (Brooks \& Roberts, 1982; Razin \& Razin, 1980), since all the restriction endonucleases that discriminate between group I and group II isolates are also sensitive to this type of restriction modification (Nelson \& McClelland, 1987). Razin \& Razin (1980) found that several species of mycoplasmas contained modified deoxynucleotides.
Analysis of $M$. pneumoniae proteins by two-dimensional SDS-PAGE demonstrated that the overall protein profiles of all mycoplasma strains within each group were identical. However, protein changes were readily detected between the two groups based upon isoelectric points, quantities of protein and the absence of specific protein species. These results further confirmed that the observed differences in DNA restriction patterns correlate with differences at the gene level. Since many of the proteins that demonstrate charge variations remain antigenic, infection by different $M$. pneumoniae clinical groups may result in modified host immune responses (Su et al., 1990a). Whether any of these observed differences contribute to the overall survival and virulence potential of these mycoplasmas is unknown.

This research was supported in part by a Texas Higher Education Coordinating Board grant, and Public Health Service grant AI 27873 from the National Institute of Allergy and Infectious Diseases.

\section{References}

AmES, G. F.-L. \& NIKAIDo, K. (1976). Two-dimensional gel electrophoresis of membrane proteins. Biochemistry 15, 616-623.

Baseman, J. B., Cole, R. M., Krause, D. C. \& Leith D. K. (1982) Molecular basis for cytadsorption of Mycoplasma pneumoniae Journal of Bacteriology 151, 1514-1522.

Brooks, J. E. \& RoberTs, R. J. (1982). Modification profiles of bacterial genomes. Nucleic Acids Research 10, 913-934.

Carle, G. F., Frank, M. \& Olson, M. V. (1986). Electrophoretic separations of large DNA molecules by periodic inversion of the electric field. Science 232, 65-68.

Chandler, D. K. F., Razin, S., Stephens, E. B., Hanasawa, R. \& BARILE, M. F. (1982). Genomic and phenotypic analyses of Mycoplasma pneumoniae strains. Infection and Immunity 38, 604-609.

ChANOCK, R. M., HAYFLICK, L. \& BARILE, M. F. (1962). Growth on artificial medium of an agent associated with atypical pneumonia and its identification as a PPLO. Proceedings of the National Academy of Sciences of the United States of America 48, 41-49.

Dallo, S. F., Horton, J. R., Su, C. J. \& Baseman, J. B. (1990). Restriction fragment length polymorphism in the cytadhesin $\mathrm{Pl}$ gene of human clinical isolates of Mycoplasma pneumoniae. Infection and Immunity 58, 2017-2020.

Davis, C. P., Cochran, S., Lisse, J., Buck, G., Dinuzzo, A. R., WeBER, T. \& BeINARZ, J. A. (1988). Isolation of Mycoplasma pneumoniae from synovial fluid samples in a patient with pneumonia and polyarthritis. Archives of Internal Medicine 148, 969-970.

Eaton, M. D., Meiklejohn, G., VAn Herick, W. \& Corey, M. (1945). Studies on the etiology of primary atypical pneumonia. II. Properties of the virus isolated and propagated in chick embryos. Journal of Experimental Medicine 82, 317-328.

FeldNER, J., Gobel, U. \& BREDT, W. (1982). Mycoplasma pneumoniae adhesin localized to tip structure by monoclonal antibody. Nature, London 298, 765-767.

Foy, H. M., Kenny, G. E., McMahan, R., Mansy, A. M. \& Grayston, J. T. (1970). Mycoplasma pneumoniae pneumonia in an urban area: five years of surveillance. Journal of the American Medical Association 214, 1666-1672.

Freundt, E. A. \& Edward, D. G. (1979). Classification and taxonomy. In The Mycoplasmas, vol. 1, Cell Biology, pp. 1-37, Edited by M. F. Barile \& S. Razin. New York: Academic Press.

Grayston, J. T., Alexander, E. R., Kenny, G. E., Clarke, E. R., Fremont, J. C. \& MACColl, W. A. (1965). Mycoplasma pneumoniae infections: clinical and epidemiologic studies. Journal of the American Medical Association 191, 369-374. 
Hu, P. C., Cole, R. M., Huang, Y. S., Graham, T. A., Gardner, D. E., Collier, A. M. \& Clyde, W. A. (1982) Mycoplasma pneumoniae infection: role of a surface protein in the attachment organelle. Science 216, 313-315.

INAMINe, J. M., DenNy, T. P., Loechel, S., ShaPer, U., HuANG, C. H., BotT, K. F., \& HU, P. (1988). Nucleotide sequence of the P1 attachment-protein gene of Mycoplasma pneumoniae. Gene 64, 217229.

JACKson, D. A. \& CoOK, P. R. (1985). A general method for preparing chromatin containing intact DNA. EMBO Journal 4, 913918.

Krause, D. C. \& Mawn, C. B. (1989). Physical analysis and mapping of the Mycoplasma pneumoniae chromosome. Abstracts of the 89th Annual Meeting of the American Society for Microbiology (New Orleans, Louisiana), 153.

LIPMAN, R. P., \& CLYDE, W. A., JR. (1969). The interrelationship of virulence, cytadsorption and peroxide formation in Mycoplasma pneumoniae (34061). Proceedings of the Society for Experimental Biological Medicine 131, 1163-1167.

Maniatis, T., Fritsch, E. F. \& J. SambrooK. (1982). Molecular Cloning: a Laboratory Manual. Cold Spring Harbor, NY: Cold Spring Harbor Laboratory.

Merril, C. R., Goldman, D. \& van KeURen, M. L. (1979). Simplified silver protein detection and image enhancement methods in polyacrylamide gels. Electrophoresis 3, 17-23.

Morowitz, H. J. \& WallaCE, D. C. (1973). Genome size and life cycle of the mycoplasmas. Annals of the New York Academy of Science 225, 63-73.

Nelson, M. \& McClelland, M. (1987). The effect of site specific methylation on restriction modification enzymes. Nucleic Acids Research 15, r219-r230.

O'Farrell, P. Z., Goodman, H. M., \& O'Farrell, P. H. (1977). High resolution two-dimensional electrophoresis of basic as well as acidic proteins. Cell 12, 1133-1142.
RaziN, S. (1985). Molecular biology and genetics of mycoplasmas (mollicutes). Microbiological Reviews 49, 419-455.

RAZIN, A. \& RAzIN, S. (1980). Methylated bases in mycoplasma DNA. Nucleic Acids Research 8, 1383-1390.

SU, C. J. \& BASEMAN, J. B. (1990). Genome size of Mycoplasma genitalium. Journal of Bacteriology 172, 4705-4707.

Su, C. J., Chavoya, A. \& Baseman, J. B. (1988). Regions of Mycoplasma pneumoniae cytadhesin P1 structural gene exist as multiple copies. Infection and Immunity 56, 3157-3161.

Su, C. J., Chavoya, A., Dallo, S. F. \& Baseman, J. B. $(1990 a)$. Sequence divergency of the cytadhesin gene of Mycoplasma pneumoniae. Infection and Immunity 58, 2669-2674.

Su, C. J., Dallo, S. F. \& Baseman, J. B. (1990 $b$ ). Molecular distinctions among clinical isolates of Mycoplasma pneumoniae. Journal of Clinical Microbiology 28, 1538-1540.

Su, C. J., TrYoN, V. V. \& BASEMAN, J. B. (1987). Cloning and sequence analysis of cytadhesin P1 gene from Mycoplasma pneumoniae. Infection and Immunity 55, 3023-3029.

Towbin, H., Staehelin, T., \& GoRDON, J. (1979). Electrophoretic transfer of proteins from polyacrylamide gels to nitrocellulose sheets: procedure and some applications. Proceedings of the National Academy of Sciences of the United States of America 76, 4350-4354.

Vu, A. C., Foy, H., CarTwright, F. D. \& KenNy, G. E. (1987). The principal protein antigens of isolates of Mycoplasma pneumoniae as measured by levels of immunoglobulin $G$ in human serum are stable in strains collected over a 10-year period. Infection and Immunity 55, 1830-1836.

Wenzel, R. P., Craven, R. B., Davis, J. A., Hendley, J. O., Hamory, B. H., \& GWALTNEY, J. M., JR (1976). Field trial of an inactivated Mycoplasma pneumoniae vaccine. I. Vaccine efficacy. Journal of Infectious Disease 134, 571-576.

Wenzel, R. \& Herrmann, R. (1988). Physical mapping of the Mycoplasma pneumoniae genome. Nucleic Acids Research 16, 83238336. 